\title{
Cooling cows efficiently with water spray: Behavioral, physiological, and production responses to sprinklers at the feed bunk
}

\author{
Jennifer M. Chen, ${ }^{*}$ Karin E. Schütz, $†$ and Cassandra B. Tucker*1 \\ *Department of Animal Science, University of California, Davis 95616 \\ †AgResearch Ltd., Hamilton 3240, New Zealand
}

\begin{abstract}
Dairies commonly mount nozzles above the feed bunk that intermittently spray cows to dissipate heat. These sprinklers use potable water-an increasingly scarce resource - but there is little experimental evidence for how much is needed to cool cows in loose housing. Sprinkler flow rate may affect the efficacy of heat abatement, cattle avoidance of spray (particularly on the head), and water waste. Our objectives were to determine how sprinkler flow rate affects cattle behavioral, physiological, and production responses when cows are given 24-h access to spray in freestall housing, and to evaluate heat abatement in relation to water use. We compared 3 treatments: sprinklers that delivered 1.3 or $4.9 \mathrm{~L} / \mathrm{min}$ (both $3 \mathrm{~min}$ on and $9 \mathrm{~min}$ off, $24 \mathrm{~h} / \mathrm{d}$ ) and an unsprayed control. Nine pairs of high-producing lactating Holstein cows received each treatment at a shaded feed bunk for $2 \mathrm{~d}$ in a replicated $3 \times 3$ Latin square design [air temperature $(\mathrm{T}): 24$-h maximum $=33 \pm 3^{\circ} \mathrm{C}$, mean $\pm \mathrm{SD}$ ]. Cows spent $5.8 \pm 0.9 \mathrm{~h} / 24 \mathrm{~h}$ (mean $\pm \mathrm{SD}$ ) at the feed bunk overall, regardless of treatment. With few exceptions, cows responded similarly to the 1.3 and $4.9 \mathrm{~L} /$ min flow rates. Sprinklers resulted in visits to the feed bunk that were on average 23 to $27 \%$ longer and 13 to $16 \%$ less frequent compared with the control, perhaps because cows avoided walking through spray. Indeed, when the sprinklers were on, cows left the feed bunk half as often as expected by chance, and when cows chose to walk through spray, they lowered their heads on average 1.7- to 3 -fold more often than in the control. Despite possible reluctance to expose their heads to spray, cows did not avoid sprinklers overall. In warmer weather, cows spent more time at the feed bunk when it had sprinklers (on average 19 to $21 \mathrm{~min} / 24 \mathrm{~h}$ for each $1^{\circ} \mathrm{C}$ increase in $\mathrm{T}$ ), likely for heat abatement benefits. Compared with the control, sprinklers resulted in 0.3 to $0.7^{\circ} \mathrm{C}$ lower body temperature from 1300 to $1500 \mathrm{~h}$ and 1700 to $2000 \mathrm{~h}$ overall and attenuated the rise in
\end{abstract}

Received December 3, 2015

Accepted February 24, 2016.

${ }^{1}$ Corresponding author: cbtucker@ucdavis.edu this measure on warmer days (for each $10^{\circ} \mathrm{C}$ increase in $\mathrm{T}$, body temperature increased by on average 0.5 to $0.7^{\circ} \mathrm{C}$ with sprinklers vs. $1.6^{\circ} \mathrm{C}$ without). Sprinkler access also resulted in milk yield that was, on average, 3.3 to $3.7 \mathrm{~kg} / 24 \mathrm{~h}$ higher than in the control treatment. In this hot and dry climate, $1.3 \mathrm{~L} / \mathrm{min}$ cooled cows more efficiently than $4.9 \mathrm{~L} / \mathrm{min}$, as the lower flow rate achieved equivalent reduction in body temperature and increase in milk yield relative to no spray, despite using $73 \%$ less water.

Key words: heat load, sprinkler, soaker, behavior

\section{INTRODUCTION}

The accumulation of heat load in cattle results in increased body temperature, decreased milk yield (West, 2003) and fertility (De Rensis and Scaramuzzi, 2003), and in extreme cases, mortality (Stull et al., 2008; Morignat et al., 2014). For heat abatement, US dairy producers commonly provide water spray $(62 \%$ of milking herds $\geq 500$ head; USDA, 2010). Relative to shade alone, spray reduces body temperature (Valtorta and Gallardo, 2004; Kendall et al., 2007; Chen et al., 2013), respiration rate (Mitlöhner et al., 2001), and localized air temperature (Frazzi et al., 2002; Kendall et al., 2007; Chen et al., 2013). This resource has also been shown to increase feed intake (Strickland et al., 1989) and milk yield (Her et al., 1988).

Along with reducing heat load in cows, minimizing the water footprint is a sustainability concern for US dairy production (von Keyserlingk et al., 2013). Spraying cattle uses potable water, which is predicted to become more limited due to decreasing rainfall, changes in precipitation patterns, and rising temperatures (Rosenstock et al., 2006). Spray is often provided at the feed bunk using soaker nozzles that deliver coarse droplets to wet through the hair coat to the skin. In addition to cooling the microclimate, spray dissipates heat from cows via evaporation when the water is turned off (similar to sweating). To allow for this, sprinklers for the entire pen of cattle are typically activated intermittently with a controller when air temperature $(\mathbf{T})$ reaches a threshold set by the dairy producer. 
Dairies vary widely in the amount of water used to cool cows (e.g., 23 to $256 \mathrm{~L} / 24 \mathrm{~h}$ per cow; G. Tresoldi, UC Davis, Davis, CA, personal communication). Applying more water (by increasing nozzle flow rate or application duration) results in diminishing returns. In a hot, humid climate, higher flow rates (8.2 and 11.7 $\mathrm{L} / \mathrm{min}$ ) did not reduce body temperature or respiration rate relative to the lowest $(5.2 \mathrm{~L} / \mathrm{min}$, applied intermittently above the freestalls; Means et al., 1992), although no unsprayed controls were tested. In California's hot, dry Mediterranean climate, we found $1.3 \mathrm{~L} / \mathrm{min}$ reduced body temperature and respiration rate relative to $0.4 \mathrm{~L} / \mathrm{min}$ and no spray, but $\geq 4.5 \mathrm{~L} / \mathrm{min}$ provided little additional cooling when cows were required to use spray (applied intermittently for $1 \mathrm{~h}$ at the feed bunk; Chen et al., 2015).

Although flow rate affects cooling when cows are required to use sprinklers, little is known about the effect of this spray attribute on behavior in loose housing. In freestalls and drylots, which house three-quarters of US dairy cows (USDA, 2010), cattle can choose whether to stand under spray. Sprinklers activate intermittently regardless of cattle presence at the feed bunk and water is wasted when they avoid spray. Loose-housed cattle use sprinklers for at least part of the day (Legrand et al., 2011; Parola et al., 2012; Chen et al., 2013), but they avoid spray to the head by lowering (Kendall et al., 2007; Schütz et al., 2011) or keeping this body part out of the spray radius (Schütz et al., 2011; Chen et al., 2013). Cows lowered their heads 5 times as often in response to $4.5 \mathrm{~L} / \mathrm{min}$ compared with $0.4 \mathrm{~L} / \mathrm{min}$ (Chen et al., 2016), likely because higher flow rates generate greater spray impact (i.e., 8-fold difference in this study). Nonetheless, cows did not avoid the higher flow rate altogether in brief tests: they did not require additional pressure from a handler to approach $4.5 \mathrm{~L} /$ min spray compared with $0.4 \mathrm{~L} / \mathrm{min}$ (delivered for 1 min in an aversion race; Chen et al., 2016) and showed no preference between these flow rates (delivered for 12 min in a choice maze; J. M. Chen, unpublished data). In a commercial setting, however, if reluctance to wet the head translates into overall avoidance of spray, this could result in reduced efficacy of heat abatement and in water waste.

Our objectives were to evaluate the effects of flow rate on behavioral, physiological, and production responses to sprinklers in freestall housing, and to evaluate heat abatement compared with water use. We predicted cows would show greater reluctance to wet their heads when encountering a higher flow rate, which could result in reduced overall use. If cows use different flow rates equally, we predicted that flow rates $\geq 1.3 \mathrm{~L} / \mathrm{min}$ would have similar effects on body temperature (based on previous work), and thus on feed intake and milk yield. Therefore, we predicted $1.3 \mathrm{~L} / \mathrm{min}$ would use water more efficiently to cool cows relative to a higher flow rate.

\section{MATERIALS AND METHODS}

\section{Animals and Housing}

The study was conducted during the summer (July to August 2013) at the University of California-Davis (UC Davis) dairy facility, with all procedures approved by the Institutional Animal Care and Use Committee. Eighteen lactating Holstein-Friesian dairy cows were used, with average parity $2.3 \pm 1.0$, DIM $199 \pm 69$, daily milk yield $45 \pm 4 \mathrm{~kg}$, and BW $721 \pm 98 \mathrm{~kg}$ (mean $\pm \mathrm{SD}) ; 15$ of the cows were pregnant.

Cows were housed in pairs ( $\mathrm{n}=9$ pairs), in 3 cohorts comprising 3 pairs each, balanced for average milk yield. Each pair of cows had an unshaded water trough and a fan (model 36-DMCH, 91.4-cm blade diameter; Future Products Corp., Mosinee, WI) mounted above each row of 4 shaded, sand-bedded freestalls (2 to 4 freestalls/ cow). They had ad libitum access to a TMR [89.3 \pm $0.6 \% \mathrm{DM}$, mean $\pm \mathrm{SD} ; 41 \%$ alfalfa hay, $41 \%$ grain mix, $8 \%$ whole cottonseed, $8 \%$ almond hulls, $1 \%$ EnerGII (Vitus Nutrition, Corcoran, CA), and 1\% mineral mix, as-fed], which was replenished during each milking. Cows were milked twice daily at 0400 and $1600 \mathrm{~h}$ in a parlor approximately $60 \mathrm{~m}$ from the home pen, for a total of $1.8 \pm 0.6 \mathrm{~h} / 24 \mathrm{~h}$ (mean $\pm \mathrm{SD}$ ). Milk yield was recorded using DairyComp 305 (Valley Agricultural Software, Tulare, CA).

\section{Treatments}

For each pair of cows, the shaded feed bunk was fitted with 2 soaker nozzles (Turbo FloodJet wide-angle flat spray tips; Spraying Systems Co., Wheaton, IL) spaced $1.9 \mathrm{~m}$ apart on a water line $1.8 \mathrm{~m}$ from the feed bunk at $2.3 \mathrm{~m}$ high. The nozzles were aimed toward the bunk and angled downward to avoid wetting the feed. The operating water pressure was $207 \mathrm{kPa}(30$ psi, $2.1 \mathrm{~kg} / \mathrm{cm}^{2}$ ) and the spray radius extended to 1.85 $\mathrm{m}$ from the feed bunk, where a black-and-white dashed line was painted on the ground. To minimize spray drift between pens, 2.4 -m-high $\times 3.7-\mathrm{m}$-long plywood partitions were placed perpendicular to the feed bunk. Spray was delivered for $3 \mathrm{~min}$ followed by $9 \mathrm{~min}$ off for 24 $\mathrm{h} / \mathrm{d}$, controlled by a cycle timer (custom; Chipponeri Electric Inc., Hilmar, CA) that triggered a solenoid (Meter-Man; Komelon USA Corp., Waukesha, WI).

There were 3 treatments: a control in which no water was applied and 2 sprinkler treatments that differed in flow rate $(1.3 \mathrm{~L} / \mathrm{min}$, model TF-VP2, $450 \mu \mathrm{m}$ average 
droplet size; $4.9 \mathrm{~L} / \mathrm{min}$, model TF-VP7.5, 660- $\mu \mathrm{m}$ average droplet size). The theoretical total spray impact $\left(\mathbf{F}_{i}\right)$ for the 1.3 and $4.9 \mathrm{~L} / \mathrm{min}$ treatments was 4.4 and $16.7 \mathrm{kPa}$, respectively, determined by using the equation $\mathrm{F}_{i}=\mathrm{Q} \times \sqrt{\mathrm{P}} \times \mathrm{K}$, where $\mathrm{Q}$ is the volumetric flow rate in $\mathrm{L} / \mathrm{min}, \mathrm{P}$ is the liquid operating pressure in $\mathrm{kg} /$ $\mathrm{cm}^{2}$, and $\mathrm{K}$ is the constant 2.354 to convert to $\mathrm{kPa}$ (Spraying Systems Co., 2015). Each treatment period lasted 2 consecutive days, and all pairs of cows received all 3 treatments in a replicated $3 \times 3$ Latin square design $(6 \mathrm{~d} /$ pair total).

\section{Environmental and Spray Measures}

A portable weather station (WS-16; NovaLynx Corp., Auburn, CA) in an unshaded area approximately 40 $\mathrm{m}$ from the experimental pens recorded ambient conditions: $\mathrm{T}\left({ }^{\circ} \mathrm{C}\right)$, black globe temperature $\left(\mathbf{B G T},{ }^{\circ} \mathrm{C}\right)$, solar radiation $\left(\mathrm{W} / \mathrm{m}^{2}\right)$, relative humidity $(\mathbf{R H}, \%)$, wind speed $(\mathbf{W S}, \mathrm{m} / \mathrm{s})$, and rainfall $(\mathrm{mm})$ at 5 -min intervals. Additional indicators of external heat load were temperature-humidity index (THI) and heat load index (HLI), calculated according to the following equations from Kelly and Bond (1971) and Gaughan et al. (2008), respectively:

$$
\begin{gathered}
\text { THI }=(1.8 \times \mathrm{T}+32)-[(0.55-0.0055 \times \mathrm{RH}) \\
\times(1.8 \times \mathrm{T}-26)], \\
\mathrm{HLI}=\text { if }[\mathrm{BGT}>25,8.62+(0.38 \times \mathrm{RH}) \\
+(1.55 \times \mathrm{BGT})+\exp (-\mathrm{WS}+2.4)-0.5 \times \mathrm{WS}], \\
\text { else }[10.66+(0.28 \times \mathrm{RH})+(1.3 \times \mathrm{BGT})-\mathrm{WS}] .
\end{gathered}
$$

To determine the microclimate above the feed bunk, $\mathrm{T}$ and $\mathrm{RH}$ were measured at 1-min intervals by loggers (Hobo U23-002 logger with RS3 solar radiation shields; Onset Computer Corp., Pocasset, MA) hung from the shade structure in front of each feed bunk (at $1.9 \mathrm{~m}$ high, to prevent cattle interference with equipment). Sprinkler water temperature was measured twice daily at 1000 and $1600 \mathrm{~h}$ with a digital thermometer (Fisher Inc., Pittsburgh, PA).

\section{Body Temperature}

Body temperature was recorded intravaginally $24 \mathrm{~h} / \mathrm{d}$ at 2-min intervals by a data logger (Minilog12-TX, accuracy: $\pm 0.1^{\circ} \mathrm{C}$, resolution: $\pm 0.015^{\circ} \mathrm{C}, 1.6 \mathrm{~cm}$ diameter $\times 7 \mathrm{~cm}$ length; Vemco Ltd., Bedford, NS, Canada) attached to a shortened, hormone-free controlled internal drug release insert (InterAg, Hamilton, New Zealand).

\section{Behavioral Measures}

The pen was recorded continuously $24 \mathrm{~h} / \mathrm{d}$ with video cameras (WV-BP334 black-and-white CCTV video cameras; Panasonic Corp. of North America, Secaucus, NJ) positioned as follows: 6 (at a height of $3.4 \mathrm{~m}$ ) recorded the shaded feed bunk area, 3 (at a height of $3.4 \mathrm{~m}$ ) recorded the water troughs and other unshaded portions of the pen, and 4 (at a height of 3.2 $\mathrm{m})$ recorded the shaded freestall area. All cameras had 13VS2812ASII lenses (Tamron, Commack, NY), were set to record at medium quality and 15 frames/s, and were connected to a digital video recorder with surveillance software (GV Surveillance System version 8.4; GeoVision Inc., Taipei, Taiwan). Individual cows were identified by their coat patterns, and $1 \mathrm{cow} /$ pair also wore a collar with reflective tape. Red holiday lights were strung throughout the pen for nighttime visibility.

Seven observers scored video recordings continuously (with 24-h periods beginning at $0400 \mathrm{~h}$ ) to determine time spent at the feed bunk, water trough, and lying down. A cow was scored as being in the feed bunk area when at least 1 hoof was on or over the painted line. Presence at the water trough was recorded beginning when any part of the cow's head, neck, or shoulder crossed the edge of the water trough, and ended when this criterion was no longer met and either front hoof also changed position. A cow was scored as lying when her flank was in contact with the ground or bedding surface. To determine interobserver reliability (Martin and Bateson, 2007), each observer collected $24 \mathrm{~h}$ of data for 1 cow and their values (on an hourly basis) were compared against those of J. M. Chen as the gold standard. For all pairs of observers, $\mathrm{r}=1.0$ (Pearson correlation) for the amount of time cows spent performing the 3 behaviors. Bouts (discrete behavioral events) were defined as lasting $\geq 1 \mathrm{~s}$, and interobserver reliability for pairs of observers was $r=1.0$ for the feed bunk and lying, and ranged from $\mathrm{r}=0.988$ to 1.0 for the water trough.

In addition, 1 observer scored chin position to determine head posture when cows entered and exited the feed bunk area. Each cow was observed for the min before all 4 hooves crossed over the painted line in either direction. During this 1-min interval, chin position was scored using one-zero sampling (Martin and Bateson, 2007). If the poll was the forward-most part of the body at any time during this interval, the chin was scored as tucked and the head was thus considered lowered (Figure 1). If the muzzle was always forward-most, the head was scored as not lowered. Intraobserver reliability was 0.883 , as determined by proportion agreement. We determined whether the spray was on or off when cows lowered their heads; on average, this was $\leq 16$ s before 


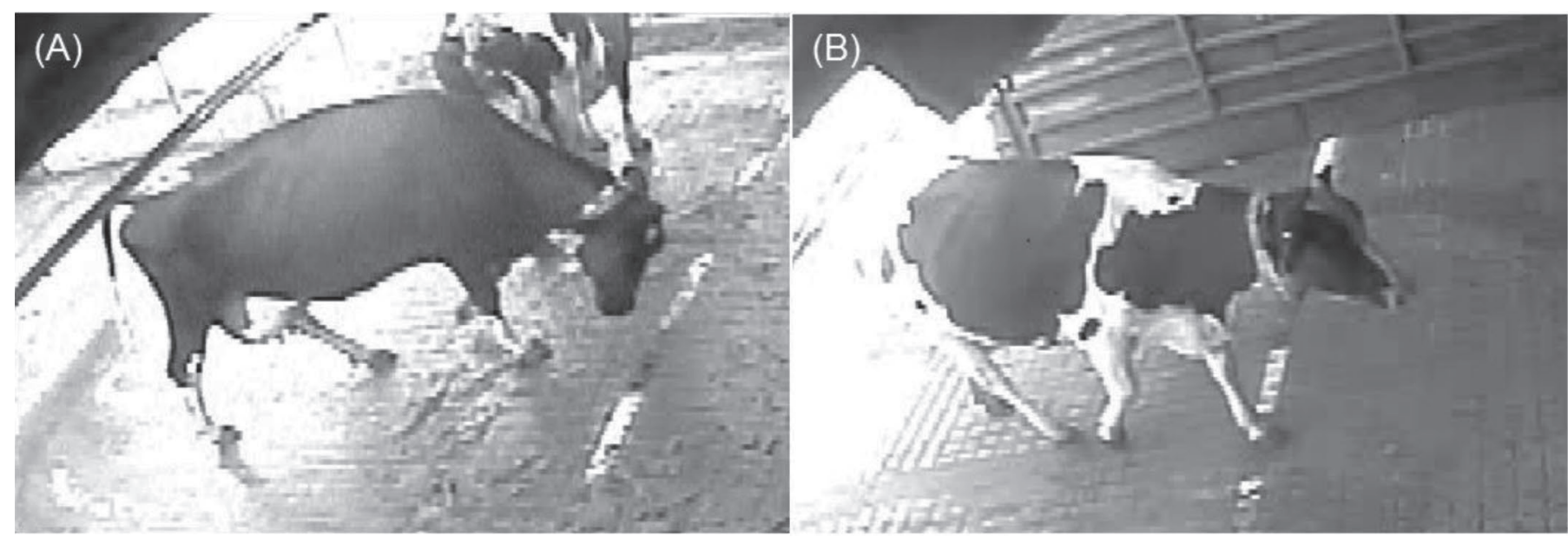

Figure 1. Head posture was evaluated when each cow entered and exited the feed bunk area. The head was scored as lowered if the poll was the forward-most part of the head (A); otherwise, the head was scored as not lowered if the muzzle was always forward (B).

cows crossed the painted line (mean $\pm \mathrm{SD}=15.3 \pm$ $15.0 \mathrm{~s}$ for entries, $15.7 \pm 17.4 \mathrm{~s}$ for exits). Based on this, for each observation where cows held their muzzles forward during the entire 1-min interval, we determined whether the spray was on or off $16 \mathrm{~s}$ before the cow crossed the painted line.

\section{Feed Intake and Moisture}

Feed intake was assessed by weighing orts daily at $0400 \mathrm{~h}$ and subtracting these from the total weight of feed delivered in the prior 24-h period. All weights were converted to a DM basis by drying samples in a $100^{\circ} \mathrm{C}$ forced-air oven for $\geq 13 \mathrm{~h}$. In addition, to evaluate whether the sprinkler treatments affected moisture levels of feed in the bunk, samples were collected from each feed bunk daily at $2300 \mathrm{~h}$ during the night check, approximately halfway between feedings.

\section{Statistical Analysis}

Dependent Variables. The effects of sprinklers on the environment in the feed bunk area were measured using microclimate $\mathrm{T}$ and $\mathrm{RH}$ above the feed bunk and DM percent of feed in the bunk. Cattle-based measures of heat load were 24-h mean and maximum body temperature; time spent in the feed bunk area, at the water trough, and lying down (number of bouts, mean bout duration, and total time); DMI; and milk yield. To examine how spray affected behavior when cows transitioned in and out of the feed bunk area, the proportion of entries and exits that occurred when the spray was on was calculated, as well as the proportion in which cows lowered their heads. All measures were averaged within each pair of cows, as this was the experimental unit ( $\mathrm{n}=9$ pairs).

Excluded Data. In the first cohort, data from $1 \mathrm{~d}$ were excluded for DMI (as $\leq 56 \mathrm{~kg}$ per pair of cows was delivered vs. $\geq 69 \mathrm{~kg}$ all other days) and milk yield (due to an error in DairyComp 305). In the second cohort, data for 1 cow were excluded (for body temperature on all days due to logger malfunction and for all other measures on the last day, as she developed clinical mastitis).

Statistical Models. Unless specified otherwise, all analyses were performed using PROC MIXED (SAS software version 9.4; SAS Institute, 2014). Each model included random terms for testing period and pair of cows within cohort, and used a variance-components covariance structure. Except where noted, all models used the Kenward-Roger degrees of freedom method (Gomez et al., 2005).

To compare overall differences among treatments, measures were averaged for the $2 \mathrm{~d}$ per treatment period, with the exception of milk yield. Only milk yield from the second day of each treatment period was included, as treatments began during milking at $0400 \mathrm{~h}$ on the first day. Each dependent variable was evaluated using a model with a fixed term for treatment. When there were significant $(P<0.05)$ treatment differences (or tendencies, $P<0.10$ ), pairwise comparisons were conducted using the PDIFF function. For microclimate $\mathrm{T}$ and $\mathrm{RH}$, the analysis was performed separately for when the spray was on and off, and used the containment degrees of freedom method. For DM percent, the 0400 and $2300 \mathrm{~h}$ samples were analyzed separately, as those taken from the $0400 \mathrm{~h}$ orts may have differed from the $2300 \mathrm{~h}$ samples based on sorting by cows. For head lowering, the comparison was performed separately for 
entries and exits to the feed bunk area, and for when the spray was on or off. For mean body temperature and time spent in the feed bunk area, the model was repeated separately for each hour.

Additional analyses were conducted to evaluate the effects of external heat load (T, THI, HLI, or BGT) on mean 24-h body temperature, DMI, and time spent at the feed bunk, water trough, and lying. A separate model was constructed for each measure of external heat load, and the fixed terms included treatment, heat load, and a treatment $\times$ heat load interaction. As milk yield responds more slowly to heat load compared with other variables (Spiers et al., 2004), the effects of heat load and DMI on the first day of each treatment period were evaluated for milk yield the next day. This analysis was performed separately for DMI and each measure of external heat load, and the fixed terms included treatment, heat load or DMI, and a treatment $\times$ heat load or DMI interaction. For each model, parameter estimates were determined using the ESTIMATE statement, including whether the slopes were significantly different from zero. When there were significant $(P<$ $0.05)$ treatment $\times$ heat load or DMI interactions (or tendencies, $P<0.10$ ), comparisons were conducted between pairs of slopes using the CONTRAST function.

To evaluate whether spray affected when cows entered or exited the feed bunk area, the proportions of entries and exits that occurred when the spray was on were compared against chance $(0.25$, as the water was on for 3 out of every $12 \mathrm{~min}$ ). This comparison was performed separately for each treatment using a 1-sample $t$-test (PROC UNIVARIATE).

\section{RESULTS}

\section{Environmental and Spray Characteristics}

Ambient Conditions and Microclimate. Ambient conditions for $24-\mathrm{h}$ periods are summarized in Table 1 and hourly $\mathrm{T}$ is shown in Figure 2A. Rainfall was 0 mm throughout the study.
We detected no treatment differences in localized $\mathrm{T}(0,1.3$, and $4.9 \mathrm{~L} / \mathrm{min}$ : spray on $=23.0,22.9$, and $22.7^{\circ} \mathrm{C}$, respectively, $\mathrm{SE}=0.8^{\circ} \mathrm{C}, F_{2,14}=0.0, P=0.960$; spray off $=23.0,22.9$, and $22.6^{\circ} \mathrm{C}$, respectively, $\mathrm{SE}=$ $0.8^{\circ} \mathrm{C}, F_{2,14}=0.1, P=0.938$ ) or $\mathrm{RH}$ (spray on $=57$, 58 , and $59 \%$, respectively, $\mathrm{SE}=2 \%, F_{2,14}=1.2, P=$ 0.338 ; spray off $=57,57$, and $59 \%$, respectively, $\mathrm{SE}=$ $\left.2 \%, F_{2,14}=1.0, P=0.391\right)$ above the feed bunk.

Feed Moisture. At 0400 h, the feed in the bunk was wetter when there were sprinklers compared with when there were none (DM: $0 \mathrm{~L} / \mathrm{min}=86.0 \%, \mathrm{SE}=0.5 \%$; overall: $F_{2,14}=4.7, P=0.028$; pairwise vs. $0 \mathrm{~L} / \mathrm{min}: P$ $\leq 0.047)$, regardless of flow rate $(1.3$ vs. $4.9 \mathrm{~L} / \mathrm{min}=$ 84.4 vs. $84.9 \%$, respectively, $\mathrm{SE}=0.5 \% ; P=0.456$ ). At $2300 \mathrm{~h}$, there was no difference in DM across treatments $(0,1.3$, and $4.9 \mathrm{~L} / \mathrm{min}=86.5,85.9$, and $86.0 \%$, respectively, $\left.\mathrm{SE}=0.5 \%, F_{2,16}=0.8, P=0.481\right)$.

Water Temperature. The average sprinkler water temperature was $26.1 \pm 1.0^{\circ} \mathrm{C}$ (mean $\pm \mathrm{SD}$; range $=$ 24.2 to $28.2^{\circ} \mathrm{C}$ ) at $1000 \mathrm{~h}$ and $28.9 \pm 1.8^{\circ} \mathrm{C}$ (range $=$ 26.0 to $32.4^{\circ} \mathrm{C}$ ) at $1600 \mathrm{~h}$.

\section{Body Temperature}

There were no differences in body temperature between the 1.3 and $4.9 \mathrm{~L} / \mathrm{min}$ treatments $(P \geq 0.354)$. When cows had access to sprinklers, compared with none, body temperature was lower from 1400 to $1500 \mathrm{~h}$ and from 1700 to $2000 \mathrm{~h}\left(F_{2,16} \geq 4.2, P \leq 0.035\right.$; Figure $2 \mathrm{~B})$, and also tended to be lower at $1300 \mathrm{~h}\left(F_{2,14}=\right.$ $3.2, P=0.073)$. Consequently, 24 -h mean body temperature tended to be lower in the sprinkler treatments relative to the control (Table 2). There was a treatment $\times \mathrm{T}$ interaction $\left(F_{2,46}=7.4, P=0.002\right.$; Figure 3$)$ : body temperature increased in warmer weather (slope estimate for control $=1.6^{\circ} \mathrm{C}$ for each $10^{\circ} \mathrm{C} \mathrm{T}$ increase, $P<0.001$ ), but this relationship was attenuated when sprinklers were provided (slope estimates for 1.3 and $4.9 \mathrm{~L} / \mathrm{min}=0.7$ and $0.5^{\circ} \mathrm{C}$, respectively, for each $10^{\circ} \mathrm{C}$ T increase, $P \leq 0.014)$. Interactions with THI, HLI, and BGT $(P \leq 0.008)$ showed similar patterns.

Table 1. Summary of daily ${ }^{1}$ ambient conditions on experimental days in July and August 2013

\begin{tabular}{lcccccccc}
\hline & \multicolumn{3}{c}{ 24-h mean } & & \multicolumn{3}{c}{ 24-h maximum } \\
\cline { 2 - 3 } \cline { 7 - 8 } Environmental variable & Mean & SD & Range & & Mean & SD & Range \\
\hline Air temperature $\left({ }^{\circ} \mathrm{C}\right)$ & 22.0 & 2.2 & $19.1-26.9$ & & 32.8 & 3.2 & $27.1-37.4$ \\
Temperature-humidity index & 67 & 3 & $64-72$ & & 78 & 3 & $73-82$ \\
Heat load index & 67 & 3 & $61-72$ & & 92 & 5 & $79-99$ \\
Black globe temperature $\left({ }^{\circ} \mathrm{C}\right)$ & 26.6 & 2.5 & $22.9-31.6$ & & 42.8 & 4.1 & $35.8-48.3$ \\
Solar radiation $\left(\mathrm{W} / \mathrm{m}^{2}\right)$ & 296 & 15 & $261-319$ & & 880 & 41 & $839-1,016$ \\
Relative humidity (\%) & 55 & 5 & $44-62$ & & 82 & 4 & $70-89$ \\
Wind speed $(\mathrm{m} / \mathrm{s})$ & 1.4 & 0.3 & $1.0-1.7$ & & 2.8 & 0.5 & $1.9-3.4$ \\
\hline
\end{tabular}

${ }^{1}$ Means, SD, and range (minimum to maximum of mean daily values) are given for $24 \mathrm{~h}$. 


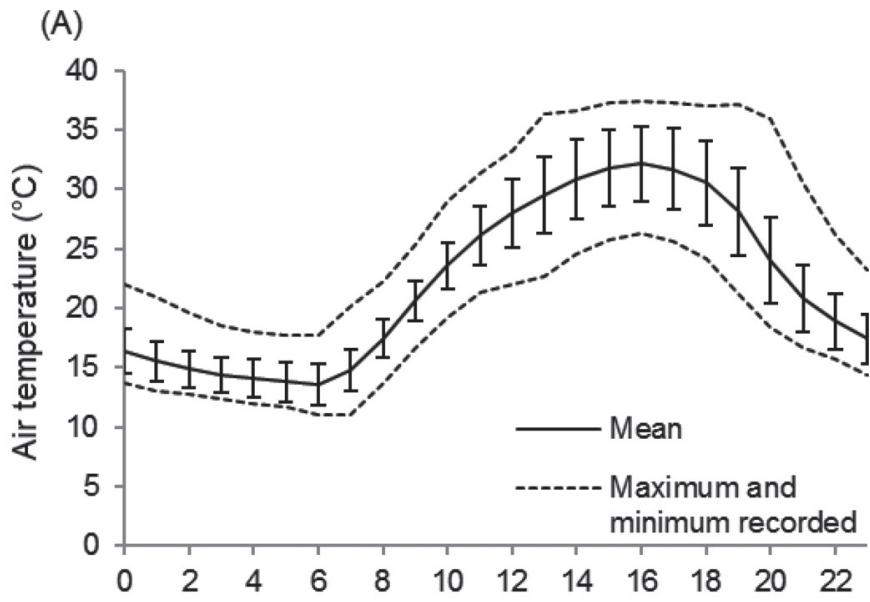

(B)

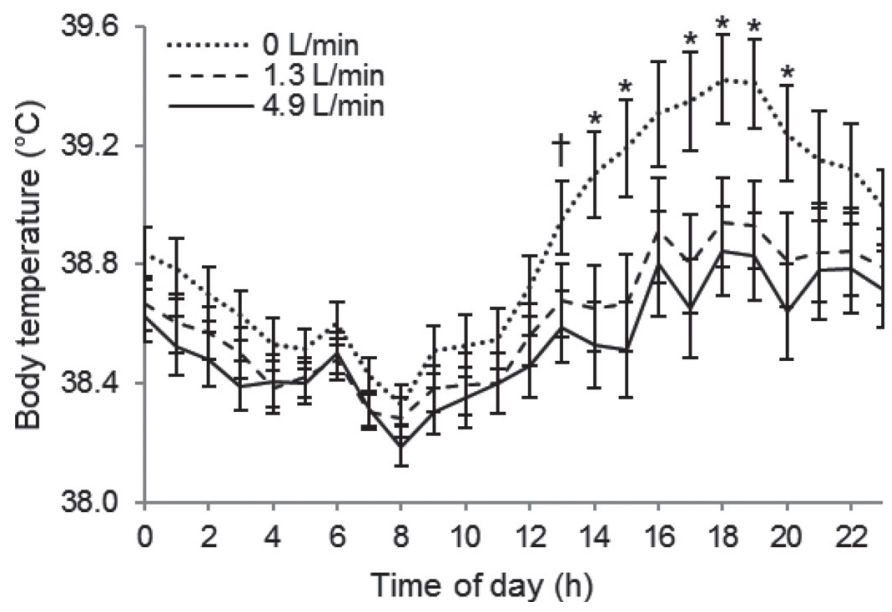

Figure 2. (A) Mean $\pm \mathrm{SD}$ air temperature by hour and the maximum and minimum air temperatures recorded when 3 cohorts of cows were exposed to each of 3 treatments for $2 \mathrm{~d}$ at a time (18 $\mathrm{d}$ total). (B) Mean \pm SE body temperature by hour ( $\mathrm{n}=9$ pairs of cows) for each of 3 treatments. Body temperature did not differ between the 1.3 and 4.9 $\mathrm{L} / \mathrm{min}$ treatments at any time of day $(P \geq 0.429)$; differences between the sprinkler treatments and the unsprayed control are indicated: $\dagger P$ $<0.08 ;{ }^{*} P<0.05$.

\section{Behavioral Responses}

Except where noted otherwise, there were no differences in behavioral responses between the 1.3 and 4.9 $\mathrm{L} /$ min treatments $(P \geq 0.424)$.

Feed Bunk. We detected no differences among treatments for time spent in the feed bunk area over 24-h periods (Table 2). However, visits to the feed bunk were longer and less frequent when sprinklers were provided compared with when they were not (Table 2). There was a tendency for a treatment $\times \mathrm{T}$ interaction $\left(F_{2,45.3}\right.$ $=2.5, P=0.095$; Figure $4 \mathrm{~A})$ : in warmer weather, cows spent more time at the feed bunk when there was spray $(1.3$ and $4.9 \mathrm{~L} / \mathrm{min}$ : slope estimates $=20.7$ and 19.1 $\mathrm{min} / 24 \mathrm{~h}$, respectively, for each $1^{\circ} \mathrm{C} \mathrm{T}$ increase, $P<$

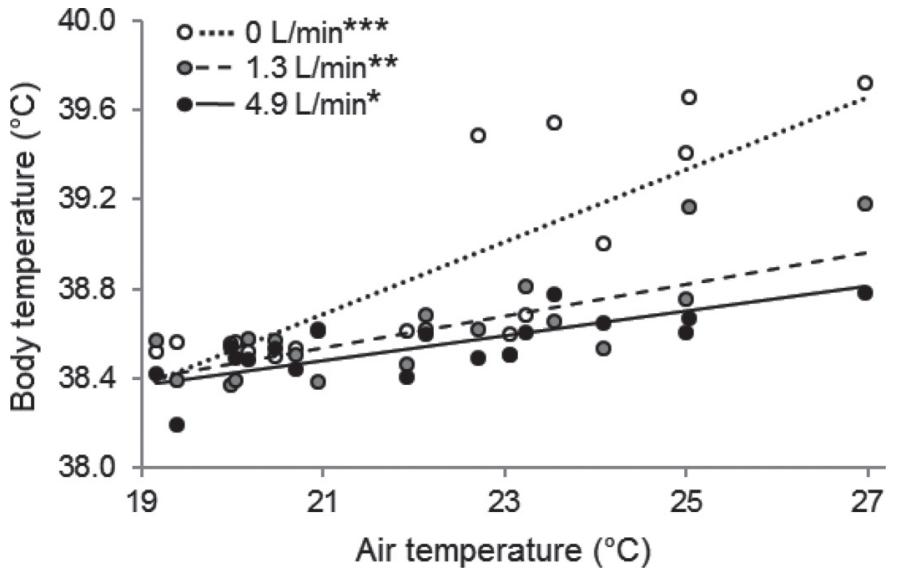

Figure 3. Mean 24-h body temperature, depending on mean 24-h air temperature. Points represent averages for each pair of cows $(\mathrm{n}=$ 9 pairs) for 24 -h periods ( $2 \mathrm{~d} /$ treatment). Treatments with slopes that differ from zero are indicated: ${ }^{*} P<0.05$; ${ }^{* *} P<0.01$; ${ }^{* * *} P<0.001$.

0.001), but not if this resource was absent (slope estimate $=7.0 \mathrm{~min} / 24 \mathrm{~h}$ for each $1^{\circ} \mathrm{C} \mathrm{T}$ increase, not significantly different from zero, $P=0.141)$. The pattern for THI was similar $\left(F_{2,44.2}=2.8, P=0.069\right)$, but the interactions with HLI and BGT were not significant $\left(F_{2,46} \leq 2.2, P \geq 0.119\right)$.

When there were $4.9 \mathrm{~L} / \mathrm{min}$ sprinklers, cows spent more time at the feed bunk at $1800 \mathrm{~h}(29.1 \mathrm{~min} / \mathrm{h}, \mathrm{SE}$ $=3.4 \mathrm{~min} / \mathrm{h}$, overall: $F_{2,14}=14.8, P<0.001$; pairwise vs. $4.9 \mathrm{~L} / \mathrm{min}: P \leq 0.002)$ and tended to at $1000 \mathrm{~h}(20.6$ $\mathrm{min} / \mathrm{h}, \mathrm{SE}=4.9 \mathrm{~min} / \mathrm{h}$, overall: $F_{2,16}=2.7, P=0.095$; pairwise vs. $4.9 \mathrm{~L} / \mathrm{min}: P \leq 0.078)$ compared with the other treatments $(0$ vs. $1.3 \mathrm{~L} / \mathrm{min}: 1800 \mathrm{~h}=13.8$ vs. $18.3 \mathrm{~min} / \mathrm{h}$, respectively, $\mathrm{SE}=3.4 \mathrm{~min} / \mathrm{h}, P=0.143$; $1000 \mathrm{~h}=11.5$ vs. $12.6 \mathrm{~min} / \mathrm{h}$, respectively, $\mathrm{SE}=4.9$ $\min / \mathrm{h}, P=0.799)$. At all other times of day, there were no treatment differences $\left(F_{2,16} \leq 1.9, P \geq 0.181\right)$.

When cows transitioned in and out of the feed bunk area, both timing and head posture depended on whether the spray was on. Cows exited the area less often than expected by chance when sprinklers were on $(P \leq 0.002$; Figure 5$)$. They also tended to enter less often than expected when $4.9 \mathrm{~L} /$ min spray was on $(P$ $=0.076)$ but not when $1.3 \mathrm{~L} / \mathrm{min}$ was on $(P=0.342)$. In the control, the proportion of entries and exits did not differ from chance $(P \geq 0.411)$. Cows tended to lower their heads when entering $\left(F_{2,16}=3.3, P=0.062\right.$; Figure $6 \mathrm{~A})$ and exiting $\left(F_{2,16}=3.7, P=0.049\right.$; Figure $6 \mathrm{~B})$ the feed bunk area more often when the sprinklers were on compared with the control. When the spray was off, this pattern tended to be reversed $\left(F_{2,16} \geq 3.0\right.$, $P \leq 0.081$ ).

Water Trough. When cows did not have sprinklers, they visited the water trough more frequently, result- 
Table 2. Cattle responses ( $\mathrm{n}=9$ pairs) when provided access to $0,1.3$, or $4.9 \mathrm{~L} / \mathrm{min}$ intermittent sprinklers above the feed bunk

\begin{tabular}{|c|c|c|c|c|c|}
\hline \multirow[b]{2}{*}{ Measure } & \multicolumn{3}{|c|}{ Sprinkler flow rate $(\mathrm{L} / \mathrm{min})$} & \multirow[b]{2}{*}{ SEM } & \multirow{2}{*}{$\begin{array}{l}\text { Overall } \\
P \text {-value }\end{array}$} \\
\hline & 0 & 1.3 & 4.9 & & \\
\hline \multicolumn{6}{|l|}{ 24-h body temperature $\left({ }^{\circ} \mathrm{C}\right)$} \\
\hline Mean & 38.9 & $38.6 \dagger$ & $38.5^{*}$ & 0.10 & 0.072 \\
\hline Maximum & 39.7 & 39.4 & 39.4 & 0.13 & 0.224 \\
\hline \multicolumn{6}{|l|}{ Time spent at the feed bunk } \\
\hline Total time $(\mathrm{h} / 24 \mathrm{~h})$ & 5.4 & 5.9 & 5.9 & 0.3 & 0.224 \\
\hline Bout length (min/bout) & 22.2 & $27.3^{* *}$ & $28.1^{* *}$ & 1.8 & 0.002 \\
\hline Bout number (per $24 \mathrm{~h}$ ) & 15.6 & $13.6^{*}$ & $13.1^{* *}$ & 1.4 & 0.008 \\
\hline \multicolumn{6}{|c|}{ Time spent at the water trough } \\
\hline Total time $(\mathrm{h} / 24 \mathrm{~h})$ & 1.3 & $1.0 \dagger$ & $0.8^{*}$ & 0.2 & 0.054 \\
\hline Bout length (min/bout) & 3.7 & 3.3 & 2.8 & 0.4 & 0.214 \\
\hline Bout number (per $24 \mathrm{~h}$ ) & 20.7 & $18.0^{*}$ & $18.0^{*}$ & 2.1 & 0.064 \\
\hline \multicolumn{6}{|l|}{ Time spent lying } \\
\hline Total time $(\mathrm{h} / 24 \mathrm{~h})$ & 11.9 & 12.2 & 12.1 & 0.5 & 0.847 \\
\hline Bout length (min/bout) & 70.0 & 67.7 & 68.9 & 4.8 & 0.698 \\
\hline Bout number (per $24 \mathrm{~h}$ ) & 10.9 & 11.2 & 10.9 & 0.8 & 0.753 \\
\hline DMI $(\mathrm{kg} / 24 \mathrm{~h})$ & 27.9 & 29.0 & 29.1 & 0.8 & 0.128 \\
\hline Milk yield $(\mathrm{kg} / 24 \mathrm{~h})$ & 42.6 & $46.3^{* *}$ & $45.9^{* *}$ & 1.1 & 0.009 \\
\hline
\end{tabular}

$\dagger P<0.10 ;{ }^{*} P<0.05 ;{ }^{*} P<0.01$ : Differences in each measure between the sprinkler treatments and the control.

ing in more time spent there (Table 2). There was a treatment $\times \mathrm{T}$ interaction $\left(F_{2,45.3}=7.4, P=0.002\right.$; Figure 4B): in warmer weather, cows spent more time at the water trough when no spray was provided (slope estimate $=16.2 \mathrm{~min} / 24 \mathrm{~h}$ for each $1^{\circ} \mathrm{C}$ T increase, $P$ $<0.001)$. This positive relationship was attenuated by $73 \%$ when $4.9 \mathrm{~L} / \mathrm{min}$ spray was available (slope estimate $=4.3 \mathrm{~min} / 24 \mathrm{~h}$ for each $1^{\circ} \mathrm{C}$ T increase, $P$ $=0.092)$, and was not detected when $1.3 \mathrm{~L} / \mathrm{min}$ was provided (slope estimate $=3.5 \mathrm{~min} / 24 \mathrm{~h}$ for each $1^{\circ} \mathrm{C}$ $\mathrm{T}$ increase, not significantly different from zero, $P=$ $0.166)$; these slopes did not differ significantly $(P=$ $0.832)$. Interactions with THI, BGT, and HLI $\left(F_{2,45.3} \geq\right.$ $5.2, P \leq 0.009)$ showed similar patterns.

Lying. We observed no differences in lying time among treatments (Table 2). Lying time decreased in warmer weather (slope estimate $=-20.9 \mathrm{~min} / 24 \mathrm{~h}$ for each $1^{\circ} \mathrm{C}$ T increase, $\left.F_{1,40.9}=50.6, P<0.001\right)$, regardless of treatment (no treatment $\times$ heat load interactions, $\left.F_{2,42.1} \leq 0.9, P \geq 0.435\right)$. The relationships were similar for THI, HLI, and BGT $\left(F_{1,40.7} \geq 37.9, P<\right.$ 0.001).

\section{DMI}

Dry matter intake did not differ among treatments overall (Table 2). There was a tendency for a treatment $\times$ THI interaction $\left(F_{2.37 .8}=2.5, P=0.097\right):$ DMI decreased in warmer weather when no or $1.3 \mathrm{~L} / \mathrm{min}$ spray was provided (slope estimates $=-0.7$ and -0.4 $\mathrm{kg} / 24 \mathrm{~h}$, respectively, for each 1 -unit THI increase, $P$ $\leq 0.025$ ) but not with $4.9 \mathrm{~L} / \mathrm{min}$ sprinklers (slope es-

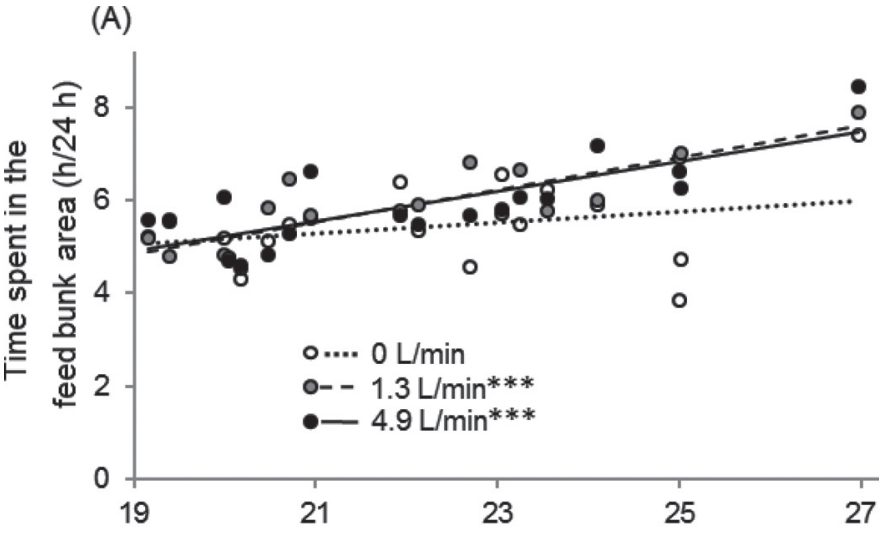

(B)

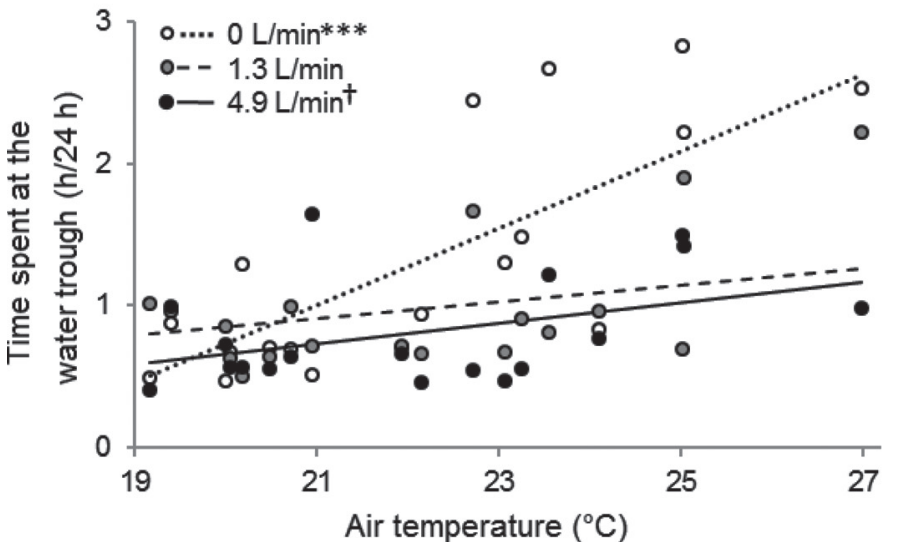

Figure 4. Mean time spent at the (A) feed bunk or (B) water trough, depending on mean 24-h air temperature. Points represent averages for each pair of cows $(\mathrm{n}=9$ pairs) for 24 -h periods $(2 \mathrm{~d} /$ treatment). Treatments with slopes that differ from zero are indicated: $\dagger P<0.10 ; * * * P<0.001$. 


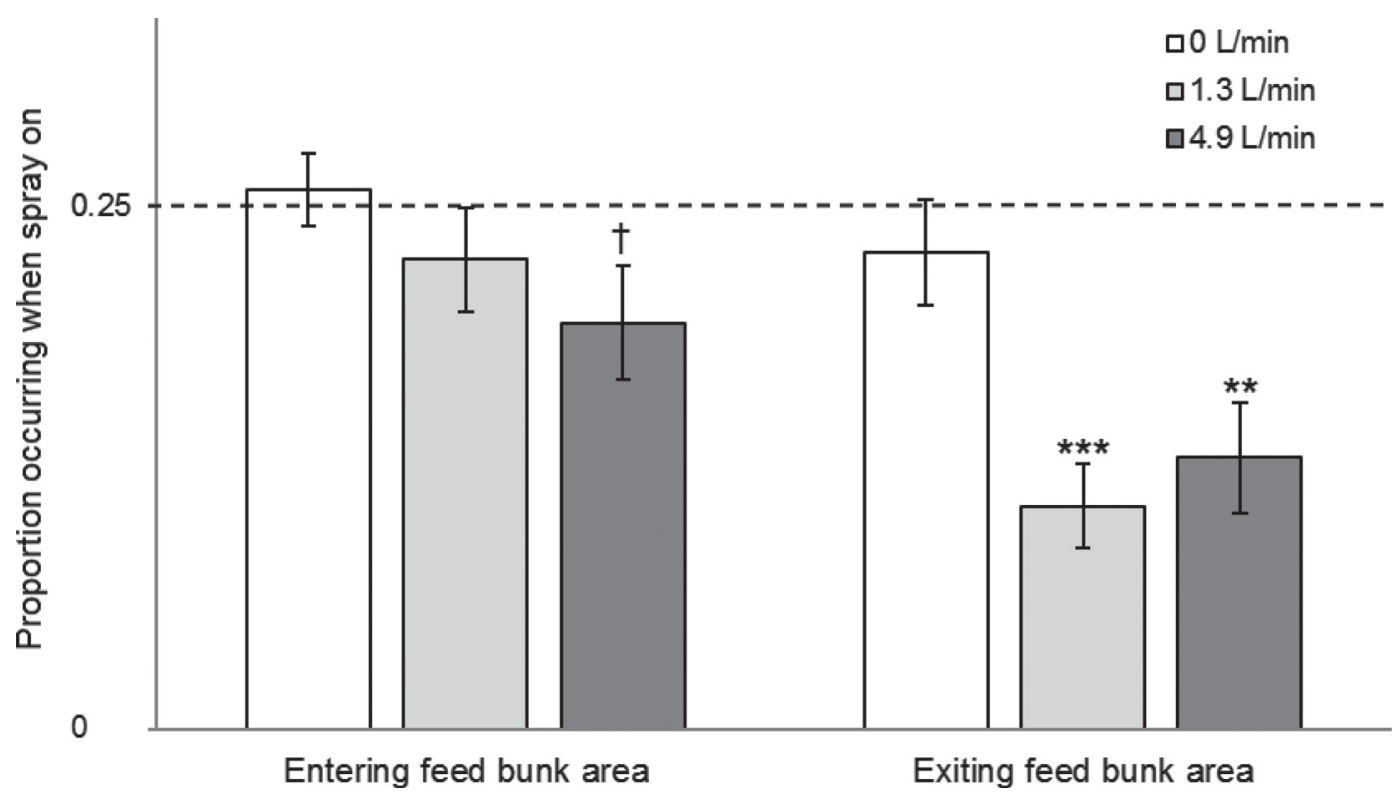

Figure 5. Proportion $\pm \mathrm{SE}$ of entries and exits cows $(\mathrm{n}=9$ pairs $)$ made to and from the feed bunk area when the spray was on, compared with chance $(---; 0.25$, as the water was on for 3 out of every $12 \mathrm{~min}, 24 \mathrm{~h} / \mathrm{d})$. Differences between observed proportions and chance are indicated: $\nmid P<0.08 ; * * P<0.01 ; * * * P<0.001$.

timate $=-0.1 \mathrm{~kg} / 24 \mathrm{~h}$ for each 1 -unit THI increase, not significantly different from zero, $P=0.500)$. Dry matter intake decreased as T, HLI, or BGT increased $\left(F_{236.2} \geq 8.0, P \leq 0.008\right)$, regardless of treatment (no treatment $\times \mathrm{T}$, HLI, or BGT interactions, $F_{2,38} \leq 2.1$, $P \geq 0.142)$.

\section{Milk Yield}

Milk yield was higher when cows had sprinklers compared with when they had none (Table 2), regardless of spray flow rate $(1.3$ vs. $4.9 \mathrm{~L} / \mathrm{min}: P=0.732)$. Within a treatment period, when DMI was higher the first day, milk yield tended to be higher the next day $\left(F_{1,16.7}=\right.$ $3.3, P=0.086$ ), regardless of treatment (no treatment $\times$ DMI interaction, $\left.F_{2,9.8}=2.5, P=0.136\right)$. Ambient conditions on the first day of a treatment period did not affect milk yield the next day (no main effect of heat load, $F_{1,11.9} \leq 0.1, P \geq 0.753$; no treatment $\times$ heat load interactions, $\left.F_{2,14.4} \leq 2.5, P \geq 0.118\right)$.

\section{DISCUSSION}

With few exceptions, dairy cows responded similarly to 1.3 and $4.9 \mathrm{~L} / \mathrm{min}$ sprinklers above the feed bunk. Changes in head position suggested that cows were reluctant to expose this body part to spray, but this did not translate into overall avoidance of sprinklers. Rather, when sprinklers were present, cows modified their behavior to maintain time spent at the feed bunk while avoiding walking through spray and getting their heads wet. In warmer conditions, cows spent more time at the feed bunk when sprinklers were provided, likely for heat abatement benefits. Sprinkler access reduced body temperature throughout the latter half of the day, mitigated the increase in this measure on warmer days, and resulted in higher milk yield. Despite using $73 \%$ less water, $1.3 \mathrm{~L} / \mathrm{min}$ sprinklers reduced heat load as effectively as $4.9 \mathrm{~L} / \mathrm{min}$ in this hot and dry Mediterranean climate.

\section{Time Budget and Body Temperature}

The amount of time cows spent at the feed bunk increased on warmer days when there were 1.3 or 4.9 $\mathrm{L} /$ min sprinklers, as in previous work using $3.3 \mathrm{~L} / \mathrm{min}$ (Chen et al., 2013). The magnitude of this relationship $\left(0.4 \mathrm{~h} / 24 \mathrm{~h}\right.$ more for each $1^{\circ} \mathrm{C} \mathrm{T}$ increase) was comparable to the increase in time cows spent using a pressure-activated shower on warmer days $(0.3 \mathrm{~h} / \mathrm{d}$ more for each $1^{\circ} \mathrm{C} \mathrm{T}$ increase; Legrand et al., 2011). Cattle preferences for feed bunks with sprinklers compared with those without also become more marked in warmer conditions (Parola et al., 2012; Chen et al., 2013). These heat load-dependent patterns may explain why we did not replicate previous findings that cows spent more time at the feed bunk overall when it had sprinklers (Chen et al., 2013) as, on average, condi- 
(A) Entering feed bunk area

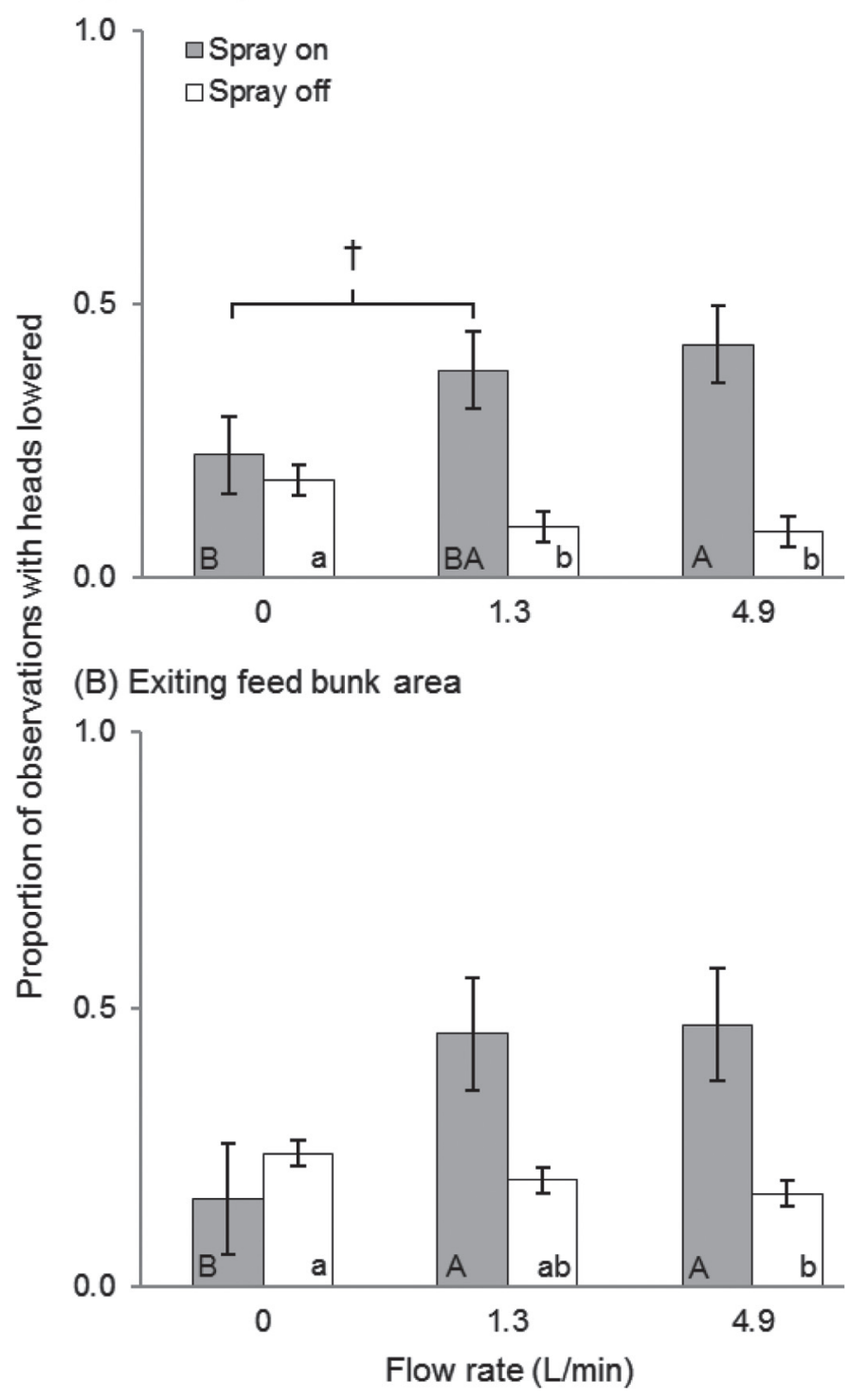

Figure 6. Proportion $\pm \mathrm{SE}$ of $(\mathrm{A})$ entries to and (B) exits from the feed bunk area in which cows $(\mathrm{n}=9$ pairs) showed lowered head position. Letters indicate significant $(P<0.05)$ differences among treatments when the spray was on (uppercase) or off (lowercase), and tendencies are indicated: $\dagger P<0.08$.

tions in the current study were milder (average 24-h maximum $\mathrm{T}=32.8$ vs. $36.0^{\circ} \mathrm{C}$, respectively; maximum observed $\mathrm{T}=37.4$ vs. $42.1^{\circ} \mathrm{C}$, respectively).

Cows likely seek spray in warmer conditions for heat abatement. Compared with when cows had no spray, both sprinkler flow rates reduced body temperature in the latter half of the day, consistent with studies in which cows had 24 -h access to $\geq 3.3 \mathrm{~L} /$ min spray (Legrand et al., 2011; Chen et al., 2013). Sprinkler access mitigated the increase in body temperature on warmer days: when cows had no spray access, this measure in- creased by $1.6^{\circ} \mathrm{C}$ for each $10^{\circ} \mathrm{C} \mathrm{T}$ increase, but sprinkler provision attenuated the magnitude of this relationship by at least half. This pattern was consistent with previous work using $3.3 \mathrm{~L} / \mathrm{min}$ (Chen et al., 2013).

Although sprinkler access reduced body temperature, we did not replicate previous work that showed spray results in a cooler microclimate (Frazzi et al., 2002; Kendall et al., 2007; Chen et al., 2013), and that higher flow rates reduce localized $\mathrm{T}$ more than lower ones (i.e., 4.5 vs. $0.4 \mathrm{~L} / \mathrm{min}$; J. M. Chen, unpublished data). This may be because we mounted data loggers above the spray to avoid cattle interference with equipment, in contrast with previous experiments, in which they were placed at cattle height and recorded conditions when no cows were present (Chen et al., 2013; J. M. Chen, unpublished data). As suggested by Frazzi et al. (2002), recording with cows present may have captured the heat transferred to the air when water evaporated directly from cattle, possibly masking treatment differences in localized $\mathrm{T}$.

When cows had no spray access, the amount of time they spent near the water trough increased on warmer days, consistent with other studies (Widowski, 2001; Schütz et al., 2010). Time spent drinking (Shultz, 1984) and water intake (Mader et al., 1997) also show this pattern, perhaps as a means to replace respiratory and cutaneous water losses that increase with heat load (Silanikove, 2000). Others have speculated that cows may stand near the water trough for a cooler microclimate (Schütz et al., 2010; Legrand et al., 2011) or to splash themselves (Ansell, 1981). As sprinklers reduce heat load, this may explain why access to this resource mitigated the relationship between warmer conditions and time spent near the water trough, both in this study and in previous work (Legrand et al., 2011).

Also as in previous studies, cows spent less time lying down on warmer days (Zähner et al., 2004; Cook et al., 2007; Schütz et al., 2010), regardless of sprinkler provision (Overton et al., 2002; Legrand et al., 2011; Chen et al., 2013). The reasons for the heat-related shift from lying to standing have been suggested to include reducing heat conducted from a warm lying surface (Silanikove, 2000), exposing greater body surface area to air movement (Ansell, 1981; Igono et al., 1987), or increasing the efficiency of respiration (Legrand et al., 2011), but these have not been explicitly examined.

\section{Avoidance of Wetting the Head}

Although sprinkler access did not affect the overall time cows spent at the feed bunk, it changed the bout structure (the frequency and length of bouts) for visits to the feed bunk. In the sprinkler treatments, visits to the sprayed feed bunk were longer but fewer than in 
the control. Similar changes in bout structure are seen when a price to access a resource is imposed experimentally by requiring animals to either perform work (rats pressing a lever repeatedly and farmed mink pushing a weighted door, respectively; Collier et al., 1990; Cooper and Mason, 2000) or navigate obstacles (mice crossing a water pool; Sherwin and Nicol, 1995, 1996). When animals are presented with higher prices, their longer but less frequent visits are interpreted as a compensatory strategy to maintain overall use. We speculate that cows may have perceived walking through spray as an obstacle, as their heads would be wetted, which may be associated with discomfort. Two aspects of their behavior when transitioning in and out of the feed bunk area supported this idea.

First, cows left the feed bunk area more often when the 1.3 or $4.9 \mathrm{~L} / \mathrm{min}$ sprinklers were off. It is possible they waited until the sprinklers were off to leave because being cooled by spray increased the benefits of staying at the feed bunk, but this would only explain why bouts were longer. In contrast, a downside associated with walking through spray would explain both the reduction in bout number and also why cows tended to approach the feed bunk less often when the $4.9 \mathrm{~L} /$ min sprinklers were on. We did not observe this pattern for $1.3 \mathrm{~L} / \mathrm{min}$ sprinklers and speculate that when cows went toward the feed bunk, they obtained at least 2 benefits - feed and heat abatement - that may have partially outweighed the downsides of walking through this spray.

Second, when cows chose to walk through spray, they lowered their heads more often compared with the unsprayed control. In a previous study, cows lowered their heads in response to $4.5 \mathrm{~L} / \mathrm{min}$ more often than both an unsprayed control and a spray of $0.4 \mathrm{~L} / \mathrm{min}$ (Chen et al., 2016), indicating that this response depends on spray impact $\left(\mathrm{F}_{i}=8.9\right.$ vs. $1.1 \mathrm{kPa}$, respectively). In the current study, however, there was no difference in head lowering between 4.9 and $1.3 \mathrm{~L} / \mathrm{min}$, despite the nearly 4-fold difference in spray impact $\left(\mathrm{F}_{i}=16.7\right.$ vs. $4.4 \mathrm{kPa}$, respectively). Together, the findings from these 2 studies suggest the threshold for head lowering is associated with spray impact $>1.1 \mathrm{kPa}$. Reluctance to wet the head has been observed in other studies in which cows lowered (Kendall et al., 2007; Schütz et al., 2011) or kept their heads out of the spray radius (Schütz et al., 2011; Chen et al., 2013) when standing under sprinklers. These responses may be attempts to reduce exposure of sensitive areas to higher-impact spray, as the ear responds to mechanical stimuli at one-sixth the level of force compared with the shoulder (Chen et al., 2016), and spray hitting the head may therefore be associated with discomfort. Cows' reluctance to expose their heads to spray did not translate into overall avoidance in the current study, as sprinklers did not reduce total time spent at the feed bunk, nor did head lowering reflect overall aversion in a previous study, as cows did not need more pressure from a handler to walk toward 4.5 L/min (Chen et al., 2016). However, in these studies, cows walked through spray only briefly, and work is needed to evaluate the animal welfare implications of sprinkling cows when they do not have the option to remove their heads from the spray radius, such as in the holding pen for the milking parlor.

\section{DMI and Milk Yield}

When cows had access to 1.3 or $4.9 \mathrm{~L} / \mathrm{min}$ sprinklers, milk yield was, on average, 3.7 and $3.3 \mathrm{~kg} / 24 \mathrm{~h}$ higher, respectively, compared with the control. Earlier studies in Israel's Mediterranean climate likewise found that intermittent spray increased milk yield by 1.5 to $2.6 \mathrm{~kg} / 24 \mathrm{~h}$ on average (Her et al., 1988; Flamenbaum et al., 1995). Dry matter intake decreased on warmer days, but $4.9 \mathrm{~L} / \mathrm{min}$ spray mitigated this relationship, consistent with what others have found when sprinklers are provided (Morrison et al., 1981; Strickland et al., 1989; Gaughan et al., 2004). When DMI was lower, milk yield tended to be lower the following day, consistent with the 1-d lag between these measures in a climate chamber (Spiers et al., 2004). Studies have shown that reduced DMI accounts for 35 to $50 \%$ of heat-related milk production losses (Rhoads et al., 2009; Wheelock et al., 2010), and other physiological mechanisms (reviewed by Baumgard and Rhoads, 2012) contribute. If these physiological mechanisms respond to spray cooling, this could explain the treatment differences we found for milk yield but not DMI. In our study, milk yield was not directly affected by ambient conditions, likely because we limited treatments to $2 \mathrm{~d}$ based on ethical concerns about depriving cows of sprinkler access in the control treatment. There is evidence for a 2-d lag between warm conditions and a decline in milk yield (West et al., 2003), and a longer study comparing different amounts of water could provide further insight into the effects of spray on DMI and milk yield.

\section{Cooling Efficiency}

With the spray schedule we used, the 1.3 and 4.9 $\mathrm{L} / \mathrm{min}$ nozzles delivered 19.5 and $73.5 \mathrm{~L} / \mathrm{h}$ per cow, respectively $(54 \mathrm{~L} / \mathrm{h}$ per cow difference). Relative to no spray, $1.3 \mathrm{~L} / \mathrm{min}$ was as effective as $4.9 \mathrm{~L} / \mathrm{min}$ for reducing body temperature and increasing milk yield, and there were no significant differences between the flow rates for either measure. Even at 2000 h, when the sprinkler treatments had the greatest average difference in body temperature $\left(<0.2^{\circ} \mathrm{C}\right)$, each additional liter per 
hour delivered by $4.9 \mathrm{~L} / \mathrm{min}$ reduced this measure by $<0.004^{\circ} \mathrm{C}$ compared with $1.3 \mathrm{~L} / \mathrm{min}$. These findings are consistent with our predictions, which were based on previous work that found applying more than $1.3 \mathrm{~L} /$ min provided little additional heat abatement when cows were required to use sprinklers for $1 \mathrm{~h} / \mathrm{d}$ (Chen et al., 2015).

Compared with typical commercial settings, this study may have wasted water in 2 ways: by spraying intermittently $24 \mathrm{~h} / \mathrm{d}$ and providing 1 nozzle/cow. To ensure consistent treatment application across different days, we activated sprinklers $24 \mathrm{~h} / \mathrm{d}$, whereas our facility, like others, normally uses a minimum $\mathrm{T}$ threshold (e.g., 21 to $27^{\circ} \mathrm{C}$; G. Tresoldi, UC Davis, Davis, CA, personal communication). Our nozzles were spaced 1.9 $\mathrm{m}$ apart, similar to the 1.8- to 2.8-m spacing on other dairies (G. Tresoldi, UC Davis, Davis, CA, personal communication), but the low feed bunk stocking density ( $<1$ cow per head gate) in our study is found on only $35 \%$ of freestall operations nationwide (USDA, 2010).

Future work should evaluate the degree of heat abatement that can be achieved with even less water. An alternative to reducing sprinkler flow rate may be to apply higher flow rates for a shorter duration. Higher flow rate nozzles generate larger droplets on average (Doble et al., 1985) and thus have lower potential for spray drift, a concern with the long, open feed bunks commonly found on larger dairies. Spray drift may explain why the moisture content of feed in the bunk averaged 54\% in another study (using 1.3 and $2.6 \mathrm{~L} /$ min nozzles; Parola et al., 2012) compared with $<16 \%$ in our study (regardless of sprinkler provision), despite nearly identical moisture levels as-fed (88.7 vs. $89.3 \%$ DM on average, respectively). In the current study, little spray may have drifted into the feed bunk because of the lack of fans in this area, or because the plywood barriers to contain spray between pairs of cows perhaps also blocked wind. As spray drift may reduce the cooling efficacy of sprinklers, future studies on larger dairies should evaluate this concern.

\section{CONCLUSIONS}

We evaluated the effects of 24-h intermittent sprinklers on behavioral, physiological, and production responses in freestall housing. Despite differing nearly 4 -fold in water use, both sprinkler flow rates (1.3 and $4.9 \mathrm{~L} / \mathrm{min}$ ) had similar effects on cattle responses to heat load. Cows showed reluctance to expose their heads to spray, but this did not translate into avoiding sprinklers overall. On warmer days, cows spent more time at the feed bunk when sprinklers were provided, likely for heat abatement. Regardless of flow rate, sprinkler access reduced body temperature throughout the latter half of the day, mitigated the increase in this measure on warmer days, and resulted in higher milk yield. Our study is the first to demonstrate that sprinklers above the feed bunk that intermittently deliver $1.3 \mathrm{~L} / \mathrm{min}$ (3.9 L per spray application) can provide efficient heat abatement for loose-housed dairy cows in a hot and dry climate.

\section{ACKNOWLEDGMENTS}

The authors are grateful to those who assisted with data collection: Alex Tsai, Pei-Yen Chao, Veronica Wang, Margaret De Luz, Steven Hsu, Esteban Aleman, Setareh Badr, Renee Dematei, Amanda Dilbeck, Zoe Hsi, Laura MacIntyre, Rianna Ragland, Ingrid Rodriguez, Matthew Warren (all affiliated with UC Davis at the time of the study), and Soraia Matarazzo (Santa Cruz State University, Brazil). Many thanks also to Joy Mench, Erin Mintline, Doug Gisi, Sharlie Folsom, the staff and interns of the UC Davis Dairy Teaching and Research Facility, Daniel Sehnert and the Animal Science farm crew, the Lillie May Richards Foundation (Davis, CA; funding for J. M. Chen), Henry A. Jastro Fund (Davis, CA), and USDA multi-state research project W2173 (Washington, DC). We gratefully acknowledge the infrastructure support of the Department of Animal Science, College of Agricultural and Environmental Sciences, and the UC Davis California Agricultural Experiment Station.

\section{REFERENCES}

Ansell, R. H. 1981. Extreme heat stress in dairy cattle and its alleviation: A case report. Pages 285-306 in Environmental Aspects of Housing for Animal Protection. J. A. Clark, ed. Butterworths, London, UK.

Baumgard, L. H., and R. P. Rhoads. 2012. Ruminant nutrition symposium: Ruminant production and metabolic responses to heat stress. J. Anim. Sci. 90:1855-1865.

Chen, J. M., K. E. Schütz, and C. B. Tucker. 2013. Dairy cows use and prefer feed bunks fitted with sprinklers. J. Dairy Sci. 96:5035-5045.

Chen, J. M., K. E. Schütz, and C. B. Tucker. 2015. Cooling cows efficiently with sprinklers: Physiological responses to water spray. J. Dairy Sci. 98:6925-6938.

Chen, J. M., K. E. Schütz, and C. B. Tucker. 2016. Sprinkler flow rate affects dairy cattle avoidance of spray to the head, but not overall, in an aversion race. Appl. Anim. Behav. Sci. (In Press). 10.1016/j. applanim.2016.03.007.

Collier, G. H., D. F. Johnson, K. A. CyBulski, and C. A. McHale. 1990. Activity patterns in rats (Rattus norvegicus) as a function of the cost of access to four resources. J. Comp. Psychol. 104:53-65.

Cook, N. B., R. L. Mentink, T. B. Bennett, and K. Burgi. 2007. The effect of heat stress and lameness on time budgets of lactating dairy cows. J. Dairy Sci. 90:1674-1682.

Cooper, J. J., and G. J. Mason. 2000. Increasing costs of access to resources cause re-scheduling of behaviour in American mink (Mustela vison): Implications for the assessment of behavioural priorities. Appl. Anim. Behav. Sci. 66:135-151.

De Rensis, F., and R. J. Scaramuzzi. 2003. Heat stress and seasonal effects on reproduction in the dairy cow: A review. Theriogenology 60:1139-1151. 
Doble, S. J., G. A. Matthews, I. Rutherford, and E. S. E. Southcombe. 1985. A system for classifying hydraulic and other atomisers into categories of spray quality. Pages 1125-1133 in Proc. Br. Crop Protection Conf. Weeds, Brighton, UK. British Crop Protection Council, London, UK.

Flamenbaum, I., D. Wolfenson, P. L. Kunz, M. Maman, and A. Berman. 1995. Interactions between body condition at calving and cooling of dairy cows during lactation in summer. J. Dairy Sci. 78:2221-2229.

Frazzi, E., L. Calamari, and F. Calegari. 2002. Productive response of dairy cows to different barn cooling systems. Trans. ASAE 45:395-405.

Gaughan, J. B., M. S. Davis, and T. L. Mader. 2004. Wetting and the physiological responses of grain-fed cattle in a heated environment. Aust. J. Agric. Res. 55:253-260.

Gaughan, J. B., T. L. Mader, S. M. Holt, and A. Lisle. 2008. A new heat load index for feedlot cattle. J. Anim. Sci. 86:226-234.

Gomez, E. V., G. B. Schaalje, and G. W. Fellingham. 2005. Performance of the Kenward-Roger method when the covariance structure is selected using AIC and BIC. Commun. Stat. Simulat. 34:377-392.

Her, E., D. Wolfenson, I. Flamenbaum, Y. Folman, M. Kaim, and A Berman. 1988. Thermal, productive, and reproductive responses of high yielding cows exposed to short-term cooling in summer. J. Dairy Sci. 71:1085-1092.

Igono, M. O., H. D. Johnson, B. J. Steevens, G. F. Krause, and M. D. Shanklin. 1987. Physiological, productive, and economic benefits of shade, spray, and fan system versus shade for Holstein cows during summer heat. J. Dairy Sci. 70:1069-1079.

Kelly, C. F., and T. E. Bond. 1971. Bioclimatic factors and their measurement. Pages 7-92 in A Guide to Environmental Research on Animals. National Research Council, ed. National Academies Press, Washington, DC.

Kendall, P. E., G. A. Verkerk, J. R. Webster, and C. B. Tucker. 2007. Sprinklers and shade cool cows and reduce insect-avoidance behavior in pasture-based dairy systems. J. Dairy Sci. 90:3671-3680.

Legrand, A., K. E. Schütz, and C. B. Tucker. 2011. Using water to cool cattle: Behavioral and physiological changes associated with voluntary use of cow showers. J. Dairy Sci. 94:3376-3386.

Mader, T. L., L. R. Fell, and M. J. McPhee. 1997. Behavior response of non-Brahman cattle to shade in commerical feedlots. Livest. Env. 5:795-802.

Martin, P., and P. Bateson. 2007. Measuring Behaviour: An Introductory Guide. 3rd ed. Cambridge University Press, Cambridge, UK.

Means, S. L., R. A. Bucklin, R. A. Nordstedt, D. K. Beede, D. R. Bray, C. J. Wilcox, and W. K. Sanchez. 1992. Water application rates for a sprinkler and fan cooling system in hot, humid climates. Trans. ASAE 8:375-379.

Mitlöhner, F. M., J. L. Morrow, J. W. Dailey, S. C. Wilson, M. L. Galyean, M. F. Miller, and J. J. McGlone. 2001. Shade and water misting effects on behavior, physiology, performance, and carcass traits of heat-stressed feedlot cattle. J. Anim. Sci. 79:2327-2335.

Morignat, E., J.-B. Perrin, E. Gay, J.-L. Vinard, D. Calavas, and V. Hénaux. 2014. Assessment of the impact of the 2003 and 2006 heat waves on cattle mortality in France. PLoS ONE 9:e93176.

Morrison, S. R., M. Prokop, and G. P. Lofgreen. 1981. Sprinkling cattle for heat stress relief: Activation temperature, duration of sprinkling and pen area sprinkled. Trans. ASAE 24:1299-1300.

Overton, M. W., W. M. Sischo, G. D. Temple, and D. A. Moore. 2002. Using time-lapse video photography to assess dairy cattle lying behavior in a free-stall barn. J. Dairy Sci. 85:2407-2413.

Parola, F., E. Hillmann, K. E. Schütz, and C. B. Tucker. 2012. Preferences for overhead sprinklers by naïve beef steers: Test of two nozzle types. Appl. Anim. Behav. Sci. 137:13-22.

Rhoads, M. L., R. P. Rhoads, M. J. VanBaale, R. J. Collier, S. R. Sanders, W. J. Weber, B. A. Crooker, and L. H. Baumgard. 2009.
Effects of heat stress and plane of nutrition on lactating Holstein cows: I. Production, metabolism, and aspects of circulating somatotropin. J. Dairy Sci. 92:1986-1997.

Rosenstock, T., S. Smukler, and T. Cavagnaro. 2006. California agricultural landscapes and climate change. Pages 3-12 in Climate Change: Challenges and Solutions for California Agricultural Landscapes. T. Cavagnaro, L. Jackson, and K. Scow, ed. California Climate Change Center, Sacramento, CA.

SAS Institute. 2014. SAS/STAT 13.2 User's Guide. SAS Institute Inc. Cary, NC.

Schütz, K. E., A. R. Rogers, N. R. Cox, J. R. Webster, and C. B. Tucker. 2011. Dairy cattle prefer shade over sprinklers: Effects on behavior and physiology. J. Dairy Sci. 94:273-283.

Schütz, K. E., A. R. Rogers, Y. A. Poulouin, N. R. Cox, and C. B. Tucker. 2010. The amount of shade influences the behavior and physiology of dairy cattle. J. Dairy Sci. 93:125-133.

Sherwin, C. M., and C. J. Nicol. 1995. Changes in meal patterning by mice measure the cost imposed by natural obstacles. Appl. Anim. Behav. Sci. 43:291-300.

Sherwin, C. M., and C. J. Nicol. 1996. Reorganization of behaviour in laboratory mice, Mus musculus, with varying cost of access to resources. Anim. Behav. 51:1087-1093.

Shultz, T. A. 1984. Weather and shade effects on cow corral activities. J. Dairy Sci. 67:868-873.

Silanikove, N. 2000. Effects of heat stress on the welfare of extensively managed domestic ruminants. Livest. Prod. Sci. 67:1-18.

Spiers, D. E., J. N. Spain, J. D. Sampson, and R. P. Rhoads. 2004. Use of physiological parameters to predict milk yield and feed intake in heat-stressed dairy cows. J. Therm. Biol. 29:759-764.

Spraying Systems Co. 2015. Industrial Hydraulic Spray Products: Technical Reference. Spraying Systems Co., Wheaton, IL.

Strickland, J. T., R. A. Bucklin, R. A. Nordstedt, D. K. Beede, and D. R. Bray. 1989. Sprinkler and fan cooling system for dairy cows in hot, humid climates. Appl. Eng. Agric. 5:231-236.

Stull, C. L., L. L. McV. Messam, C. A. Collar, N. G. Peterson, A. R. Castillo, B. A. Reed, K. L. Andersen, and W. R. VerBoort. 2008. Precipitation and temperature effects on mortality and lactation parameters of dairy cattle in California. J. Dairy Sci. 91:4579-4591.

USDA. 2010. Facility characteristics and cow comfort on U.S. Dairy Operations, 2007. UDSA-Animal and Plant Health Inspection Service-Veterinary Services, Centers for Epidemiology and Animal Health, Fort Collins, CO.

Valtorta, S. E., and M. R. Gallardo. 2004. Evaporative cooling for Holstein dairy cows under grazing conditions. Int. J. Biometeorol. $48: 213-217$.

von Keyserlingk, M. A. G., N. P. Martin, E. Kebreab, K. F. Knowlton, R. J. Grant, M. Stephenson II, C. J. Sniffen, J. P. Harner III, A. D. Wright, and S. I. Smith. 2013. Invited review: Sustainability of the US dairy industry. J. Dairy Sci. 96:5405-5425.

West, J. W. 2003. Effects of heat-stress on production in dairy cattle. J. Dairy Sci. 86:2131-2144.

West, J. W., B. G. Mullinix, and J. K. Bernard. 2003. Effects of hot, humid weather on milk temperature, dry matter intake, and milk yield of lactating dairy cows. J. Dairy Sci. 86:232-242.

Wheelock, J. B., R. P. Rhoads, M. J. VanBaale, S. R. Sanders, and L. H. Baumgard. 2010. Effects of heat stress on energetic metabolism in lactating Holstein cows. J. Dairy Sci. 93:644-655.

Widowski, T. 2001. Shade-seeking behavior of rotationally-grazed cows and calves in a moderate climate. Pages 632-639 in Proc. Int. Livest. Env. Symp., Louisville, KY. American Society of Agricultural Engineers, St. Joseph, MI.

Zähner, M., L. Schrader, R. Hauser, M. Keck, W. Langhans, and B. Wechsler. 2004. The influence of climatic conditions on physiological and behavioural parameters in dairy cows kept in open stables. Anim. Sci. 78:139-147. 